\title{
STUDI PENATAAN TAMAN SEKOLAH PENERIMA ADIWIYATA DI KABUPATEN LANGKAT DITINJAU DARI SEGI PRINSIP DESAIN TAMAN
}

\author{
Meri Agustina ${ }^{1 *}$, Daulat Saragi ${ }^{2 *}$ \\ Program Studi Pendidikan Seni Rupa, Jurusan Seni Rupa, Fakultas Bahasa dan Seni \\ Universitas Negeri Medan \\ Email: meri_agustina96@yahoo.com
}

\begin{abstract}
ABSTRAK
Penelitian ini bertujuan untuk (1) melihat bagaimana penataan taman sekolah penerima Adiwiyata di Kabupaten Langkat melalui sudut pandang desain, dan (2) menilai sejauh mana penataan taman dengan menerapkan prinsip-prinsip desain taman pada sekolah penerima Adiwiyata di Kabupaten Langkat. Waktu penelitian selama 1 bulan yaitu pada Februari hingga Maret 2016. Lokasi penelitian adalah daerah Langkat, Sumatera Utara. Populasi dalam penelitian ini berjumlah 32 sekolah penerima Adiwiyata, dan sampel berjumlah 4 sekolah penerima Adiwiyata. Penelitian ini menggunakan metode deskriptif kualitatif dengan menguraikan penataan taman masing-masing sekolah yang diteliti berdasarkan instrumen penilaian penataan taman oleh tim penilai. Hasil kajian 4 sekolah penerima Adiwiyata menunjukkan bahwa, (1) Penataan taman pada SD. Negeri No. 058111 Kampung Satu sudah memenuhi empat prinsip desain taman dengan baik, yaitu kesatuan pada keseimbangan bersifat statis atau formal, baik simetris maupun asimetris, pusat perhatian pada bentuk dan ukuran, serta irama dan pergerakan bersifat progresif, dan berselang. (2) Penataan taman pada SD. Negeri No. 050728 Pekan Tanjung Pura sudah memenuhi empat prinsip desain taman dengan baik, yaitu kesatuan pada keseimbangan bersifat statis atau formal, baik simetris maupun asimetris, pusat perhatian pada bentuk, serta irama dan pergerakan bersifat pengulangan, dan progresif. (3) Penataan taman pada SMP. Negeri 1 Stabat sudah memenuhi tiga prinsip desain taman dengan cukup baik, yaitu kesatuan pada keseimbangan bersifat statis atau formal, baik simetris maupun asimetris, serta irama dan pergerakan bersifat pengulangan, progresif, dan berselang. (4) Penataan taman pada SMA. Negeri 1 Padang Tualang sudah memenuhi tiga prinsip desain taman dengan baik, yaitu kesatuan pada keseimbangan bersifat statis atau formal, baik simetris maupun asimetris, serta irama dan pergerakan bersifat pengulangan, dan progresif.
\end{abstract}

Kata Kunci: Penataan Taman, Prinsip Desain Taman, dan Adiwiyata

\section{PENDAHULUAN}

Taman pada dasarnya adalah pengaturan elemen tumbuhan, batu, air, dan pepohonan yang ditata dengan baik dan indah. Keindahan taman akan memberikan rasa nyaman dan tenang dalam kegiatan mengajar dan belajar di sekolah. Taman-taman di sekolah penerima Adiwiyata di Kabupaten Langkat dibuat tertata rapi dan terpelihara. Sementara pada 
kebanyakan sekolah masih belum memperhatikan faktor tersebut. Bahkan masih ada sekolah yang tidak memiliki taman, sehingga sekolah tampak panas dan gersang, tanaman hanya dibiarkan tumbuh liar, pada area taman yang luas hanya ditanami beberapa batang pohon saja, dan penataan tanaman pada beberapa sekolah kurang bervariasi.

Penataan dan pengelolaan taman perlu dikembangkan pada sekolah-sekolah dengan menggunakan metode yang sama dengan sekolah penerima Adiwiyata atau metode yang lebih baik. Tetapi belum ada titik tolak untuk mengukur efek visual pada taman-taman sekolah tersebut. Sehingga perlu dilihat bagaimana pengelolaan lingkungan atau penataan taman sekolah yang dijalankan bila dilihat dari sudut pandang desain, dan perlu diketahui seberapa jauh penataan dan penerapan prinsip desain taman pada taman sekolah penerima Adiwiyata tersebut.

Berdasarkan latar belakang, maka identifikasi masalah sebagai berikut:
1. Masih banyak sekolah yang tidak memperhatikan masalah penataan dan pemeliharaan taman.

2. Belum ada titik tolak untuk mengukur efek visual pada tamantaman sekolah penerima Adiwiyata di Kabupaten Langkat.

3. Bagaimana penataan taman sekolah penerima Adiwiyata di Kabupaten Langkat dilihat dari sudut pandang desain?

4. Sejauh mana penerapan prinsip desain taman pada sekolah penerima Adiwiyata di Kabupaten Langkat?

Melihat beberapa cakupan masalah di atas, maka masalah dibatasi pada:

1. Penataan taman sekolah penerima Adiwiyata di Kabupaten Langkat akan dilihat dari sudut pandang desain.

2. Penilaian terhadap penataan dan penerapan prinsip desain taman pada sekolah penerima Adiwiyata di Kabupaten Langkat akan dilakukan oleh tim penilai dengan menggunakan instrumen penilaian.

Melalui pembatasan masalah, kemudian dirumuskan sebagai berikut: 
1. Bagaimana penataan taman sekolah penerima Adiwiyata dilihat dari sudut pandang desain?

2. Seberapa jauh penataan dan penerapan prinsip desain taman pada sekolah penerima Adiwiyata menurut penilaian tim penilai?

Tujuan penelitian ini adalah:

1. Untuk menganalisis bagaimana penataan taman sekolah penerima Adiwiyata di Kabupaten Langkat melalui sudut pandang desain.

2. Untuk mengetahui sejauh mana penataan taman tersebut menerapkan prinsip-prinsip desain taman.

\section{METODE PENELITIAN}

\section{Ruang Lingkup Taman}

a. Pengertian Taman

Taman berkaitan dengan ruang terbuka hijau binaan dan bersifat sebagai area hijau. Menurut Ahmed, taman diciptakan dengan tujuan menghadirkan keindahan yang ditentukan dari pemilihan material, komposisi warna, bentuk, serta keharmonisan desain (Ahmed, 2011: 10-11).

b. Jenis dan Konsep Taman

$$
\text { Manfaat penelitian yang }
$$

diharapkan adalah:

1. Sebagai sumber bahan/referensi ilmiah, khususnya dalam bidang desain taman (desain eksterior).

2. Sebagai bahan masukan bagi Pemerintah Kabupaten Langkat, khususnya Dinas Pendidikan dan Pengajaran Kabupaten Langkat, Badan Lingkungan Hidup Kabupaten Langkat,serta pihak sekolah penerima Adiwiyata di Kabupaten Langkat.

3. Sebagai bahan masukan bagi peneliti, juga sebagai pengalaman dalam penelitian di kemudian hari.

Jenis taman dibedakan menjadi tiga, yaitu taman formal, taman nonformal, dan taman kombinasi.

The formal garden which is usually based on mathematically arranged geometric shapes; informal garden that flows seamlessly; and a combination garden that combine features of both the formal and the informal garden (Williams, 2007: 16-18).

Uraian di atas dapat diterjemahkan sebagai berikut:
Taman formal selalu memperhitungkan seluruh bagian secara matematis dengan bentuk 
geometris; taman non-formal merupakan kebalikan dari taman formal, dimana taman dibuat dengan bentuk yang tidak memiliki kesamaan satu sama lain; serta taman kombinasi yang merupakan kombinasi dari taman formal dan taman non-formal.

Konsep taman atau Ruang Terbuka Hijau (RTH) saat ini disesuaikanmenurut fungsi dan orang yang akan menggunakan taman tersebut atau disesuaikan dengan alam lingkungan di sekitarnya, sehingga tidak terbatas jumlah dan bentuknya.

RTH atau taman perlu mempunyai konsep dasar yang mengakomodasi beberapa fungsi, yaitu: meningkatkan kualitas lingkungan, memenuhi kebutuhan akan ruang rekreasi luar (out door), serta menyediakan ruang sosialisasi dan kebersamaan. Konsep dasar tersebut dikembangkan secara teknis mencakup acuan luas minimal, jenis ruang, desain, fasilitas, tata hijau dan jenis tanaman, serta pengelolaannya (Siskayati, 2009).

\section{c. Taman Sekolah Penerima Adiwiyata}

Konsep taman di sekolah penerima Adiwiyata menanamkan pentingnya berbudaya lingkungan.Fontenot et al (2010: 4) dalam buku yang berjudul, "Steps to Growing a Successful School Garden" mengemukakan sebagai berikut:
The primary goal of a school garden is to allow the students to grow plants from start to finish. Students are given responsibilities to care for living organisms. Teamwork, social skills, healthy food alternatives, math, science, art and physical education can all be taught in the garden area.

Uraian di atas menjelaskan bahwa:

Hasil utama dari adanya taman sekolah adalah untuk mengajarkan siswa tentang menanam dari awal hingga akhir. Siswa diberikan tanggungjawab untuk peduli mengelola lingkungan. Kerjasama, keterampilan sosial, alternatif makanan sehat, matematika, ilmu pengetahuan, dan ilmu fisik dapat diperoleh dalam areal taman.

\section{d. Fungsi Taman}

Taman umumnya didominasi oleh unsur tanaman atau tumbuhan dan pepohonan.

Tanaman dapat menciptakan iklim mikro, yaitu dapat menurunkan suhu sekitar, memberi kelembaban yang cukup, dan kadar oksigen yang bertambah. Tanaman juga dapat menyerap atau mengurangi karbondioksida yang dihasilkan dari kegiatan industri, kendaraan bermotor, dan sebagainya. Pengembangan ruang terbuka hijau akan mampu memperbaiki kondisi tanah, sebagai peluang mengembangkan keanekaragaman hayati, dan menjadi habitat bagi satwa seperti burung (Hakim, 2014: 35-37). 
e. Prinsip Desain Taman

Beberapa prinsip desain dalam penataan taman dijelaskan oleh Hakim (2014: 144-166) dalam bukunya "Komponen Perancangan Arsitektur Lansekap" di antaranya sebagai berikut:

1) Kesatuan merupakan prinsip hubungan antara keseimbangan, gerakan, penekanan, kesederhanaan, kontras, proporsi, dan ruang yang saling melengkapi. Kesatuan adalah hasil akhir dalam komposisi ketika semua hubungan prinsip rancangan secara harmonis memiliki penampilan yang memuaskan,

2) Keseimbangan berarti persamaan berat, perhatian atau daya tarik dari berbagai elemen dengan ukuran, warna, dan jumlah unsur dalam komposisi sebagai sarana mencapai kesatuan tekanan visual suatu komposisi antara unsur-unsur yang ada pada taman,

3) Pusat perhatian atau penekanan dan aksentuasi menonjolkan satu unsur agar lebih tampak terlihat dalam komposisi susunan elemen lansekap, serta

4) Irama dan pergerakan atau pengulangan unsur-unsur lansekap dipergunakan pada tempat yang berbeda dalam suatu tapak, sehingga membentuk suatu ikatan atau hubungan visual dari bagianbagian berbeda yang dapat diciptakan melalui penempatan

\section{Penilai}

Melalui filsafat seni, upaya penilaian terhadap seni membuahkan pemikiran berupa pandangan tentang benda seni (karya seni) sebagai proses kreasi seniman, adanya pencipta seni (seniman), penikmat seni (publik seni), konteks seni, nilai seni, dan pengalaman seni (Budianto, 2007: 124-125).

\section{Material}

Material terbagi atas material keras, dan material lunak. Material keras seperti kayu, batu, pasir, bahan metal, dan bahan plastik. Material lunak seperti tanaman, pepohonan, dan air. Bahan Material dapat direkayasa pada bentuk, tekstur, warna, maupun ukuran.

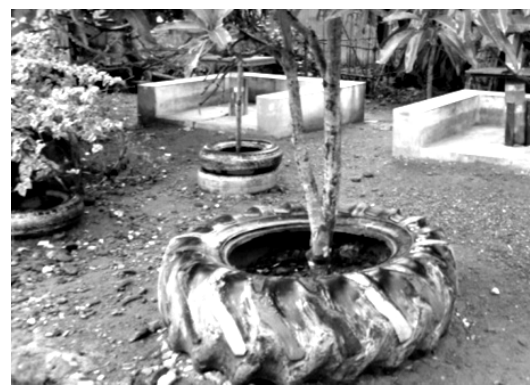

Gambar 2.11. Ban Bekas sebagai Pot sekaligus Tempat Duduk (Sumber:

Dokumentasi Pribadi).

\section{Sirkulasi (Jalanan)}

Aspek sirkulasi dalam taman merupakan sirkulasi manusia dalam pergerakannya. Sirkulasi (jalanan) memiliki pengaruh tersendiri sesuai 
dengan bentuk dan jarak yang akan ditempuh.

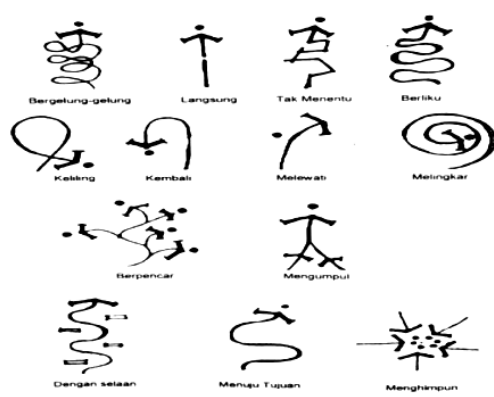

Gambar 2.15. Berbagai Bentuk Sirkulasi (Sumber: Komponen Perancangan Arsitektur Lansekap hlm. 194).

\section{Tata Hijau}

Aspek tata hijau pada areal taman meliputi karakter tanaman, dan peletakan tanaman. Karakter tanaman dapat dilihat dari bentuk tajuk, batang dan cabang, daun, bunga, dan sebagainya.

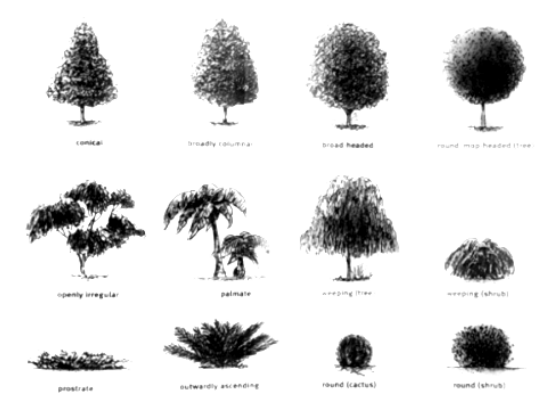

Gambar 2.16. Berbagai Bentuk Tajuk Tanaman (Sumber: The Garden Designer hlm. 141).

\section{Kenyamanan}

Aspek taman yang sangat penting untuk dipertimbangkan adalah kenyamanan. Kenyamanan dipengaruhi oleh faktor bentuk keseluruhan pada taman yang menyangkut masalah keindahan.

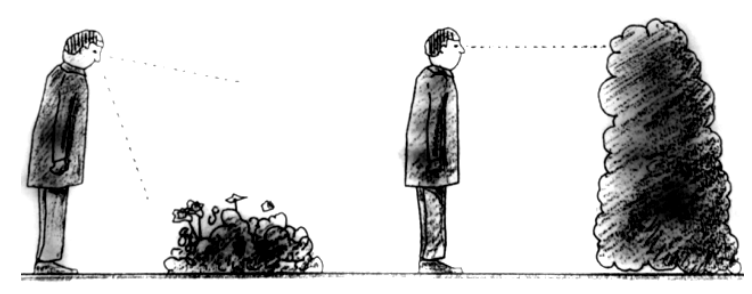

Gambar 2.17. Persepsi terhadap Peletakan Tanaman (Sumber: The Garden Designer hlm. 29).

\section{Penilaian Prinsip Desain Taman}

Kesatuan merupakan paduan dari beberapa prinsip desain yang selaras dan dapat dinikmati.Dalam hal ini merupakan paduan dari keseimbangan, pusat perhatian, serta irama dan pergerakan yang saling melengkapi sebagai hasil akhir dalam komposisi ketika semua hubungan prinsip rancangan secara harmonis memiliki penampilan yang memuaskan.

\section{Konsep Penilaian}

Penilaian prinsip desain taman sekolah penerima Adiwiyata yaitu kesatuan dinilai pada keseimbangan, pada pusat perhatian, serta pada irama dan pergerakan, keseimbangan dinilai bersifat statis, dan bersifat dinamis, pusat perhatian dinilai pada ukuran, pada bentuk, pada tata letak, pada warna dan tekstur, serta pada ruang, serta irama dan pergerakan dinilai bersifat pengulangan, bersifat progresif, dan bersifat 
berselang.Aspek yang akan dinilai dalam penelitian ini yaitu material pada rekayasa bentuk, rekayasa tekstur, rekayasa warna, dan rekayasa ukuran, sirkulasi (jalanan) pada bentuk sirkulasi, tata hijau pada peletakan tanaman, dan kenyamanan terhadap keindahan yang dimuat dalam satu instrumen penilaian bersambung dan tiap sekolah dinilai oleh tiga orang penilai. Penilaian dilakukan dengan membubuhi checklist $(\sqrt{ })$ dan atau penulisan angka. Dalam instrumen turut disertakan dokumentasi foto, serta indikator penilaian. Penilaian akan dibahas dalam penghitungan sederhana dalam jumlah dan rata-rata, menjadi bentuk naratif ke penilaian yaitu sangat baik (4), baik (3), cukup baik (2), atau kurang baik (1).

Penelitian dilaksanakan di empat sekolah di Kabupaten Langkat penerima Adiwiyata Mandiri tahun 2013, yaituSMA. Negeri 1 Padang Tualang, Jl. Batang Serangan Kecamatan Padang Tualang, SMP. Negeri 1 Stabat, Jl. K.H. Zainul Arifin Kecamatan Stabat, SD. Negeri 058111 Kampung Satu, Jl. Sawit Seberang Kecamatan Sawit Seberang, serta SD.
Negeri 050728 Pekan Tanjung Pura, J1. Bambu Runcing Kecamatan Tanjung Pura. Secara teknis, kegiatan penelitian dilaksanakan pada Februari 2016 hingga Maret 2016.

Istilah populasi didefinisikan sebagai kelompok besar dari kesatuan sampel, sedangkan sampel merupakan bagian yang representatif dari populasi (Neuman dalam Herdiansyah, 2010: 113).

Pemilihan sampel dalam penelitian ini diambil tidak secara acak (non random sampling atau non probability sampling), yaitu teknik purposeful sampling, dimana sampel ditentukan berdasarkan kepada ciriciri yang dimiliki oleh subjek yang sesuai dengan tujuan penelitian (Herdiansyah, 2010: 106).

Data populasi dalam penelitian ini berjumlah 32 sekolah penerima Adiwiyata (tingkat Provinsi), Adiwiyata Nasional (tingkat Nasional/membina 10 sekolah), dan Adiwiyata Mandiri (tingkat Nasional/berhasil membina sekolah Adiwiyata) di Kabupaten Langkat mulai tahun 2011-2014. Pemilihan sampel dalam penelitian ini ditentukan berdasarkan kriteria kesamaan penerimaan penghargaan dan 
kelompok tahun.Kelompok sekolah tersebut, terdiri dari SD. Negeri 050728 Pekan Tanjung Pura,SD.

Negeri 058111 Kampung Satu, SMP. Negeri 1 Stabat, dan SMA. Negeri 1 Padang Tualang. Metode dalam penelitian yang dilakukan adalah observasi berupa studi atau pengamatan. Metode studi atau pengamatan ini dipilih karena sesuai dan memiliki beberapa kelebihan dibanding metode lain.

Kelebihan pengamatan mengarah kepada perspektif yang menyeluruh, dalam pendekatannya berorientasi pada penemuan, pengamat berpeluang untuk melihat sesuatu yang bisa jadi terlepas dari kesadaran secara rutin, juga informasi yang tidak diperoleh dengan pendekatan lain, serta Tabel 3.4. Penilaian Penataan Taman Berdasarkan Prinsip Desain Taman oleh Tiga Penilai (Gabungan)

NAMA SEKOLAH :

PENILAI : P1: Zainul Fadli, S. E., P2: Yosmalia Hasibuan, P3: (Guru/Tim Adiwiyata Sekolah)

Penggabungan nilai dilakukan dengan menuliskan angka pada kolom yang tersedia, dengan memperhatikan penilaian tim penilai.

\begin{tabular}{|c|c|c|c|c|c|c|c|c|c|c|c|c|c|c|c|c|}
\hline \multirow{4}{*}{ No. } & \multirow{4}{*}{$\begin{array}{l}\text { Aspek Penilaian } \\
\text { Penataan Taman }\end{array}$} & \multicolumn{15}{|c|}{ Prinsip Desain Taman dan Penilaian } \\
\hline & & \multicolumn{9}{|c|}{ 1. Kesatuan, pada: } & \multicolumn{6}{|c|}{ 2. Keseimbangan, bersifat: } \\
\hline & & \multicolumn{3}{|c|}{ Keseimbangan } & \multicolumn{3}{|c|}{$\begin{array}{c}\text { Pusat } \\
\text { Perhatian }\end{array}$} & \multicolumn{3}{|c|}{$\begin{array}{l}\text { Irama dan } \\
\text { Pergerakan }\end{array}$} & \multicolumn{3}{|c|}{ Statis } & \multicolumn{3}{|c|}{ Dinamis } \\
\hline & & P1 & $\mathbf{P 2}$ & P3 & P1 & P2 & $\mathbf{P 3}$ & P1 & $\mathbf{P 2}$ & P3 & P1 & P2 & P3 & P1 & $\mathbf{P 2}$ & $\mathbf{P 3}$ \\
\hline \multirow[t]{4}{*}{1.} & $\begin{array}{l}\text { Material: } \\
\text { - Rekayasa Bentuk }\end{array}$ & & & & & & & & & & & & & & & \\
\hline & - Rekayasa Tekstur & & & & & & & & & & & & & & & \\
\hline & - Rekayasa Warna & & & & & & & & & & & & & & & \\
\hline & - Rekayasa Ukuran & & & & & & & & & & & & & & & \\
\hline 2. & $\begin{array}{l}\text { Sirkulasi (Jalanan): } \\
\text { - Bentuk Sirkulasi }\end{array}$ & & & & & & & & & & & & & & & \\
\hline
\end{tabular}


Gorga Jurnal Seni Rupa

Fakultas Bahasa dan Seni

Universitas Negeri Medan

Volume 7, Nomor 1, Januari - Juni 2018

http://jurnal.unimed.ac.id/2012/index.php/gorga

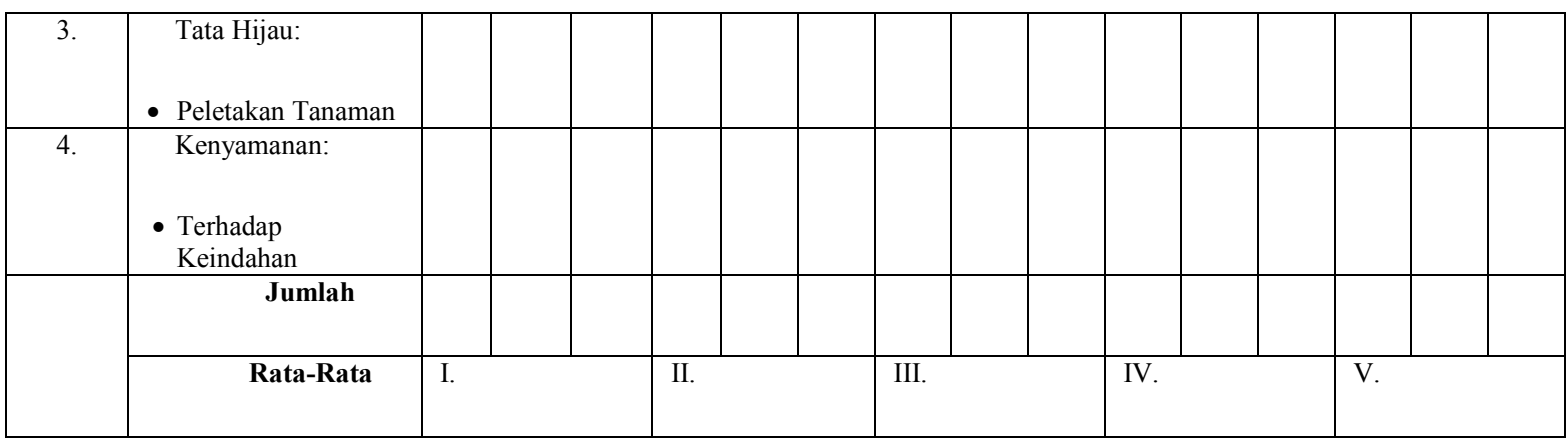

\begin{tabular}{|c|c|c|c|c|c|c|c|c|c|c|c|c|c|c|c|c|c|c|c|c|c|c|c|c|c|}
\hline \multirow{5}{*}{$\begin{array}{l}\mathbf{N} \\
\mathbf{o} .\end{array}$} & \multirow{5}{*}{$\begin{array}{c}\text { Aspek Penilaian } \\
\text { Penataan } \\
\text { Taman }\end{array}$} & \multicolumn{24}{|c|}{ Prinsip Desain Taman dan Penilaian } \\
\hline & & \multicolumn{15}{|c|}{ 3. Pusat Perhatian, pada: } & \multicolumn{9}{|c|}{$\begin{array}{c}\text { 4. Irama dan Pergerakan, } \\
\text { bersifat: }\end{array}$} \\
\hline & & \multicolumn{3}{|c|}{ Ukuran } & \multicolumn{3}{|c|}{ Bentuk } & \multicolumn{3}{|c|}{$\begin{array}{l}\text { Tata } \\
\text { Letak }\end{array}$} & \multicolumn{3}{|c|}{$\begin{array}{c}\text { Warna } \\
\text { dan } \\
\text { Tekstur }\end{array}$} & \multicolumn{3}{|c|}{ Ruang } & \multicolumn{3}{|c|}{$\begin{array}{l}\text { Pengu- } \\
\text { langan }\end{array}$} & \multicolumn{3}{|c|}{ Progresif } & \multicolumn{3}{|c|}{$\begin{array}{l}\text { Berselan } \\
\mathrm{g}\end{array}$} \\
\hline & & $\mathbf{P}$ & $\mathbf{P}$ & $\mathbf{P}$ & $\mathbf{P}$ & $\mathbf{P}$ & $\mathbf{P}$ & $\mathbf{P}$ & $\mathbf{P}$ & $\mathbf{P}$ & $\mathbf{P}$ & $\mathbf{P}$ & $\mathbf{P}$ & $\mathbf{P}$ & $\mathbf{P}$ & $\mathbf{P}$ & $\mathbf{P}$ & $\mathbf{P}$ & $\mathbf{P}$ & $\mathbf{P}$ & $\mathbf{P}$ & $\mathbf{P}$ & $\mathbf{P}$ & & $\mathbf{P}$ \\
\hline & & 1 & 2 & 3 & 1 & 2 & 3 & 1 & 2 & 3 & 1 & 2 & 3 & 1 & 2 & 3 & 1 & 2 & 3 & 1 & 2 & 3 & 1 & 2 & 3 \\
\hline \multirow[t]{4}{*}{1.} & Material: & & & & & & & & & & & & & & & & & & & & & & & & \\
\hline & $\begin{array}{l}\text { - Rekayasa } \\
\text { Tekstur }\end{array}$ & & & & & & & & & & & & & & & & & & & & & & & & \\
\hline & - Rekayasa Warna & & & & & & & & & & & & & & & & & & & & & & & & \\
\hline & $\begin{array}{l}\text { - Rekayasa } \\
\text { Ukuran }\end{array}$ & & & & & & & & & & & & & & & & & & & & & & & & \\
\hline 2. & $\begin{array}{l}\text { Sirkulasi } \\
\text { (Jalanan): }\end{array}$ & & & & & & & & & & & & & & & & & & & & & & & & \\
\hline & - Bentuk Sirkulasi & & & & & & & & & & & & & & & & & & & & & & & & \\
\hline 3. & $\begin{array}{l}\text { Tata Hijau: } \\
\text { - Peletakan } \\
\text { Tanaman } \\
\end{array}$ & & & & & & & & & & & & & & & & & & & & & & & & \\
\hline 4. & $\begin{array}{l}\text { Kenyamanan: } \\
\text { - Terhadap } \\
\text { Keindahan }\end{array}$ & & & & & & & & & & & & & & & & & & & & & & & & \\
\hline & Jumlah & & & & & & & & & & & & & & & & & & & & & & & & \\
\hline & Rata-Rata & VI & & & $\mathrm{V}$ & & & VI & & & IX & & & $\mathrm{X}$. & & & $\mathrm{XI}$ & & & $\mathrm{XI}$ & & & $\mathrm{XI}$ & & \\
\hline
\end{tabular}

Tabel 3.5. Nilai Rata-Rata dari Tiga Penilai Penataan Taman Sekolah Penerima Adiwiyata

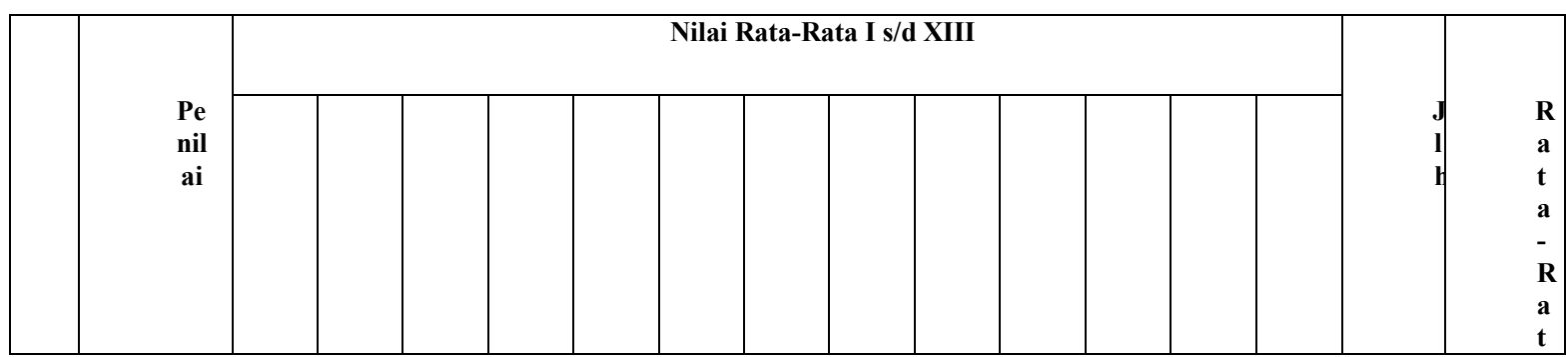


Gorga Jurnal Seni Rupa

Fakultas Bahasa dan Seni

Universitas Negeri Medan

Volume 7, Nomor 1, Januari - Juni 2018

http://jurnal.unimed.ac.id/2012/index.php/gorga

\begin{tabular}{|l|l|l|l|l|l|l|l|l|l|l|l|l|l|l|}
\hline & & & & & & & & & & & & & & \\
\hline \\
\hline $\begin{array}{l}\text { Pen } \\
\text { Ilai } \\
\text { I }\end{array}$
\end{tabular}

$\begin{array}{lll} & \text { Keterangan: } & \\ \text { A. } & \text { Nilai 4 } & \text { : Sangat Baik } \\ \text { B. } & \text { Nilai 3 } & \text { : Baik } \\ \text { C. } & \text { Nilai 2 } & \text { : Cukup Baik } \\ \text { D. } & \text { Nilai 1 } & \text { : Kurang Baik } \\ \text { E. } & \text { Penilai I } & \text { : Zainul Fadli, S. E. } \\ \text { F. } & \text { Penilai II } & \text { : Yosmalia Hasibuan } \\ \text { G. } & \text { Penilai III } & \text { : Guru/Tim Adiwiyata Sekolah }\end{array}$

Tabel 3.6. Indikator Penilaian Prinsip Desain Taman (Berdasarkan Hakim, 2014: 144-166).

\begin{tabular}{|c|c|c|c|c|}
\hline \multirow{2}{*}{$\begin{array}{l}\text { Prinsip } \\
\text { Desain } \\
\text { Taman }\end{array}$} & \multicolumn{4}{|c|}{ Indikator Penilaian } \\
\hline & 4 (Sangat Baik) & 3 (Baik) & 2 (Cukup Baik) & 1 (Kurang Baik) \\
\hline $\begin{array}{l}\begin{array}{l}\text { Kesatu } \\
\text { an, } \\
\text { pada: }\end{array} \\
\text { - Keseimban } \\
\text { gan }\end{array}$ & \begin{tabular}{lr} 
Terdapat \\
kesamaan \\
warna, mentuk, \\
ukuran maupun \\
bersifat yang \\
maupun formal \\
formal non- \\
diterapkan dengan \\
\multicolumn{2}{l}{ sangat baik }
\end{tabular} & $\begin{array}{l}\text { Terdapat kesamaan } \\
\text { bentuk, warna, } \\
\text { maupun ukuran } \\
\text { yang bersifat } \\
\text { formal maupun } \\
\text { non-formal yang } \\
\text { diterapkan dengan } \\
\text { baik }\end{array}$ & $\begin{array}{l}\text { Terdapat kesamaan } \\
\text { bentuk, warna, } \\
\text { maupun ukuran } \\
\text { yang bersifat } \\
\text { formal maupun } \\
\text { non-formal yang } \\
\text { diterapkan dengan } \\
\text { cukup baik }\end{array}$ & $\begin{array}{l}\text { Terdapat kesamaan } \\
\text { bentuk, warna, } \\
\text { maupun ukuran } \\
\text { yang bersifat } \\
\text { formal maupun } \\
\text { non-formal yang } \\
\text { diterapkan dengan } \\
\text { kurang baik }\end{array}$ \\
\hline $\begin{array}{l}\text { - Pusat } \\
\text { Perhatian }\end{array}$ & $\begin{array}{l}\text { Terdapat } \\
\text { komponen sebagai } \\
\text { aksen yang } \\
\text { menarik perhatian } \\
\text { dan diterapkan } \\
\text { dengan sangat baik }\end{array}$ & $\begin{array}{l}\text { Terdapat } \\
\text { komponen sebagai } \\
\text { aksen yang } \\
\text { menarik perhatian } \\
\text { dan diterapkan } \\
\text { dengan baik }\end{array}$ & $\begin{array}{l}\text { Terdapat } \\
\text { komponen sebagai } \\
\text { aksen yang } \\
\text { menarik perhatian } \\
\text { dan diterapkan } \\
\text { dengan cukup baik }\end{array}$ & \begin{tabular}{lr}
\multicolumn{2}{l}{ Terdapat } \\
komponen & sebagai \\
aksen ryang \\
menarik perhatian \\
dan diterapkan \\
dengan & kurang \\
baik &
\end{tabular} \\
\hline $\begin{array}{l}\text { - Irama dan } \\
\text { Pergerakan }\end{array}$ & $\begin{array}{l}\text { Terdapat } \\
\text { pengulangan } \\
\text { bentuk, warna, } \\
\text { maupun ukuran } \\
\text { yang sama, atau } \\
\text { pada satu bagian } \\
\text { tertentu memiliki } \\
\text { progres berbeda } \\
\text { dengan yang lain, } \\
\text { ataupun berselang } \\
\text { yang diterapkan }\end{array}$ & $\begin{array}{l}\text { Terdapat } \\
\text { pengulangan } \\
\text { bentuk, warna, } \\
\text { maupun ukuran } \\
\text { yang sama, atau } \\
\text { pada satu bagian } \\
\text { tertentu memiliki } \\
\text { progres berbeda } \\
\text { dengan yang lain, } \\
\text { ataupun berselang } \\
\text { yang diterapkan }\end{array}$ & $\begin{array}{l}\text { Terdapat } \\
\text { pengulangan } \\
\text { bentuk, warna, } \\
\text { maupun ukuran } \\
\text { yang sama, atau } \\
\text { pada satu bagian } \\
\text { tertentu memiliki } \\
\text { progres berbeda } \\
\text { dengan yang lain, } \\
\text { ataupun berselang } \\
\text { yang diterapkan }\end{array}$ & $\begin{array}{l}\text { Terdapat } \\
\text { pengulangan } \\
\text { bentuk, warna, } \\
\text { maupun ukuran } \\
\text { yang sama, atau } \\
\text { pada satu bagian } \\
\text { tertentu memiliki } \\
\text { progres berbeda } \\
\text { dengan yang lain, } \\
\text { ataupun berselang } \\
\text { yang diterapkan } \\
\text { dengan kurang }\end{array}$ \\
\hline
\end{tabular}


Gorga Jurnal Seni Rupa

Fakultas Bahasa dan Seni

Universitas Negeri Medan

Volume 7, Nomor 1, Januari - Juni 2018

http://jurnal.unimed.ac.id/2012/index.php/gorga

\begin{tabular}{|c|c|c|c|c|}
\hline & dengan sangat baik & dengan baik & dengan cukup baik & baik \\
\hline $\begin{array}{r}\begin{array}{r}\text { Keseim } \\
\text { bangan }\end{array} \\
\text { bersifat: } \\
\text { - Statis }\end{array}$ & $\begin{array}{lr}\text { Terdapat } & \text { sifat } \\
\text { formal dan } \\
\text { simetris yaitu } \\
\text { memiliki } \\
\text { kesamaan ukuran, } \\
\text { berat, bentuk atau } \\
\text { pola bentuknya, } \\
\text { kesamaan warna, } \\
\text { tekstur, selang, } \\
\text { dan variasi yang } \\
\text { diberikan dan } \\
\text { diterapkan dengan } \\
\text { sangat baik }\end{array}$ & $\begin{array}{lr}\text { Terdapat } & \text { sifat } \\
\text { formal } & \text { dan } \\
\text { simetris } & \text { yaitu } \\
\text { memiliki } & \\
\text { kesamaan ukuran, } \\
\text { berat, bentuk atau } \\
\text { pola bentuknya, } \\
\text { kesamaan warna, } \\
\text { tekstur, selang, } \\
\text { dan variasi yang } \\
\text { diberikan dan } \\
\text { diterapkan dengan } \\
\text { baik }\end{array}$ & $\begin{array}{lr}\text { Terdapat } & \text { sifat } \\
\text { formal dan } \\
\text { simetris yaitu } \\
\text { memiliki } \\
\text { kesamaan ukuran, } \\
\text { berat, bentuk atau } \\
\text { pola bentuknya, } \\
\text { kesamaan warna, } \\
\text { tekstur, selang, } \\
\text { dan variasi yang } \\
\text { diberikan dan } \\
\text { diterapkan dengan } \\
\text { cukup baik }\end{array}$ & $\begin{array}{l}\text { Terdapat sifat } \\
\text { formal dan } \\
\text { simetris yaitu } \\
\text { memiliki } \\
\text { kesamaan ukuran, } \\
\text { berat, bentuk atau } \\
\text { pola bentuknya, } \\
\text { kesamaan warna, } \\
\text { tekstur, selang, } \\
\text { dan variasi yang } \\
\text { diberikan dan } \\
\text { diterapkan dengan } \\
\text { kurang baik }\end{array}$ \\
\hline - Dinamis & 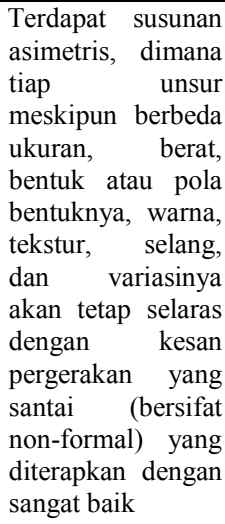 & $\begin{array}{l}\text { Terdapat } \\
\text { asimetris, dimanan } \\
\text { tiap unsur } \\
\text { meskipun berbeda } \\
\text { ukuran, berat, } \\
\text { bentuk atau pola } \\
\text { bentuknya, warna, } \\
\text { tekstur, selang, } \\
\text { dan variasinya } \\
\text { akan tetap selaras } \\
\text { dengan kesan } \\
\text { pergerakan yang } \\
\text { santai (bersifat } \\
\text { non-formal) yang } \\
\text { diterapkan dengan } \\
\text { baik }\end{array}$ & $\begin{array}{l}\text { Terdapat } \\
\text { asimetris, dimanan } \\
\text { tiap unsur } \\
\text { meskipun berbeda } \\
\text { ukuran, berat, } \\
\text { bentuk atau pola } \\
\text { bentuknya, warna, } \\
\text { tekstur, selang, } \\
\text { dan variasinya } \\
\text { akan tetap selaras } \\
\text { dengan kesan } \\
\text { pergerakan yang } \\
\text { santai (bersifat } \\
\text { non-formal) yang } \\
\text { diterapkan dengan } \\
\text { cukup baik }\end{array}$ & $\begin{array}{l}\text { Terdapat susunan } \\
\text { asimetris, dimana } \\
\text { tiap unsur } \\
\text { meskipun berbeda } \\
\text { ukuran, berat, } \\
\text { bentuk atau pola } \\
\text { bentuknya, warna, } \\
\text { tekstur, selang, } \\
\text { dan variasinya } \\
\text { akan tetap selaras } \\
\text { dengan kesan } \\
\text { pergerakan yang } \\
\text { santai (bersifat } \\
\text { non-formal) yang } \\
\text { diterapkan dengan } \\
\text { kurang baik }\end{array}$ \\
\hline $\begin{array}{l}\begin{array}{l}\text { Pusat } \\
\text { Perhati } \\
\text { an, } \\
\text { pada: }\end{array} \\
\text { - Ukuran }\end{array}$ & $\begin{array}{l}\text { Terdapat material } \\
\text { dengan ukuran } \\
\text { berbeda dengan } \\
\text { material lain yang } \\
\text { diterapkan dengan } \\
\text { sangat baik }\end{array}$ & $\begin{array}{lr}\text { Terdapat material } \\
\text { dengan ukuran } \\
\text { berbeda dengan } \\
\text { material lain yang } \\
\text { diterapkan dengan } \\
\text { baik }\end{array}$ & $\begin{array}{lr}\text { Terdapat material } \\
\text { dengan ukuran } \\
\text { berbeda dengan } \\
\text { material lain yang } \\
\text { diterapkan dengan } \\
\text { cukup baik }\end{array}$ & $\begin{array}{l}\text { Terdapat material } \\
\text { dengan ukuran } \\
\text { berbeda dengan } \\
\text { material lain yang } \\
\text { diterapkan dengan } \\
\text { kurang baik }\end{array}$ \\
\hline - Bentuk & $\begin{array}{l}\text { Terdapat material } \\
\text { dengan bentuk } \\
\text { berbeda dengan } \\
\text { material lain yang } \\
\text { diterapkan dengan } \\
\text { sangat baik }\end{array}$ & $\begin{array}{l}\text { Terdapat material } \\
\text { dengan bentuk } \\
\text { berbeda dengan } \\
\text { material lain yang } \\
\text { diterapkan dengan } \\
\text { baik }\end{array}$ & $\begin{array}{l}\text { Terdapat material } \\
\text { dengan bentuk } \\
\text { berbeda dengan } \\
\text { material lain yang } \\
\text { diterapkan dengan } \\
\text { cukup baik }\end{array}$ & $\begin{array}{l}\text { Terdapat material } \\
\text { dengan bentuk } \\
\text { berbeda dengan } \\
\text { material lain yang } \\
\text { diterapkan dengan } \\
\text { kurang baik }\end{array}$ \\
\hline - Tata Letak & $\begin{array}{l}\text { Terdapat material } \\
\text { dengan peletakan } \\
\text { berbeda dengan } \\
\text { material lain yang } \\
\text { diterapkan dengan } \\
\text { sangat baik }\end{array}$ & $\begin{array}{l}\text { Terdapat material } \\
\text { dengan peletakan } \\
\text { berbeda dengan } \\
\text { material lain yang } \\
\text { diterapkan dengan } \\
\text { baik }\end{array}$ & $\begin{array}{l}\text { Terdapat material } \\
\text { dengan peletakan } \\
\text { berbeda dengan } \\
\text { material lain yang } \\
\text { diterapkan dengan } \\
\text { cukup baik }\end{array}$ & $\begin{array}{l}\text { Terdapat material } \\
\text { dengan peletakan } \\
\text { berbeda dengan } \\
\text { material lain yang } \\
\text { diterapkan dengan } \\
\text { kurang baik }\end{array}$ \\
\hline $\begin{array}{l}\text { - Warna dan } \\
\text { Tekstur }\end{array}$ & $\begin{array}{lr}\text { Terdapat } & \text { material } \\
\text { dengan } & \text { warna } \\
\text { maupun tekstur } \\
\text { berbeda dengan } \\
\text { material lain yang } \\
\text { diterapkan dengan } \\
\text { sangat baik }\end{array}$ & $\begin{array}{lr}\text { Terdapat } & \text { material } \\
\text { dengan } & \text { warna } \\
\text { maupun } & \text { tekstur } \\
\text { berbeda dengan } \\
\text { material lain yang } \\
\text { diterapkan dengan } \\
\text { baik }\end{array}$ & $\begin{array}{lr}\text { Terdapat } & \text { material } \\
\text { dengan } & \text { warna } \\
\text { maupun tekstur } \\
\text { berbeda dengan } \\
\text { material lain yang } \\
\text { diterapkan dengan } \\
\text { cukup baik }\end{array}$ & $\begin{array}{lr}\text { Terdapat material } \\
\text { dengan warna } \\
\text { maupun tekstur } \\
\text { berbeda dengan } \\
\text { material lain yang } \\
\text { diterapkan dengan } \\
\text { kurang baik }\end{array}$ \\
\hline - Ruang & \begin{tabular}{lr}
\multicolumn{2}{c}{ Terdapat irama } \\
dan pergerakan \\
pada ruang yang \\
berbeda dengan \\
irama ran
\end{tabular} & \begin{tabular}{lr}
\multicolumn{2}{l}{ Terdapat irama } \\
dan pergerakan \\
pada ruang yang \\
berbeda dengan \\
irama ran
\end{tabular} & $\begin{array}{l}\text { Terdapat irama } \\
\text { dan pergerakan } \\
\text { pada ruang yang } \\
\text { berbeda dengan } \\
\text { irama ran }\end{array}$ & \begin{tabular}{lr}
\multicolumn{2}{l}{ Terdapat irama } \\
dan pergerakan \\
pada ruang yang \\
berbeda dengan \\
irama ran
\end{tabular} \\
\hline
\end{tabular}


http://jurnal.unimed.ac.id/2012/index.php/gorga

\begin{tabular}{|c|c|c|c|c|}
\hline & $\begin{array}{l}\text { pergerakan yang } \\
\text { lain dan diterapkan } \\
\text { dengan sangat baik }\end{array}$ & $\begin{array}{l}\text { pergerakan yang } \\
\text { lain dan diterapkan } \\
\text { dengan baik }\end{array}$ & $\begin{array}{l}\text { pergerakan yang } \\
\text { lain dan diterapkan } \\
\text { dengan cukup baik }\end{array}$ & $\begin{array}{lr}\text { pergerakan } & \text { yang } \\
\text { lain dan diterapkan } \\
\text { dengan kurang } \\
\text { baik }\end{array}$ \\
\hline 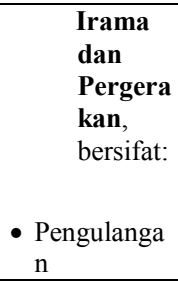 & $\begin{array}{l}\text { Terdapat } \\
\text { pengulangan } \\
\text { bentuk, warna, } \\
\text { maupun ukuran } \\
\text { yang sama dan } \\
\text { diterapkan dengan } \\
\text { sangat baik }\end{array}$ & $\begin{array}{l}\text { Terdapat } \\
\text { pengulangan } \\
\text { bentuk, warna, } \\
\text { maupun ukuran } \\
\text { yang sama dan } \\
\text { diterapkan dengan } \\
\text { baik }\end{array}$ & $\begin{array}{l}\text { Terdapat } \\
\text { pengulangan } \\
\text { bentuk, warna, } \\
\text { maupun ukuran } \\
\text { yang sama dan } \\
\text { diterapkan dengan } \\
\text { cukup baik }\end{array}$ & $\begin{array}{l}\text { Terdapat } \\
\text { pengulangan } \\
\text { bentuk, warna, } \\
\text { maupun ukuran } \\
\text { yang sama dan } \\
\text { diterapkan dengan } \\
\text { kurang baik }\end{array}$ \\
\hline - Progresif & $\begin{array}{l}\text { Terdapat susunan } \\
\text { bentuk, warna, } \\
\text { maupun ukuran } \\
\text { yang sama dan } \\
\text { pada salah satunya } \\
\text { memiliki } \\
\text { perbedaan yang } \\
\text { diterapkan dengan } \\
\text { sangat baik }\end{array}$ & $\begin{array}{l}\text { Terdapat susunan } \\
\text { bentuk, warna, } \\
\text { maupun ukuran } \\
\text { yang sama dan } \\
\text { pada salah satunya } \\
\text { memiliki } \\
\text { perbedaan yang } \\
\text { diterapkan dengan } \\
\text { baik }\end{array}$ & $\begin{array}{l}\text { Terdapat susunan } \\
\text { bentuk, warna, } \\
\text { maupun ukuran } \\
\text { yang sama dan } \\
\text { pada salah satunya } \\
\text { memiliki } \\
\text { perbedaan yang } \\
\text { diterapkan dengan } \\
\text { cukup baik }\end{array}$ & $\begin{array}{l}\text { Terdapat susunan } \\
\text { bentuk, warna, } \\
\text { maupun ukuran } \\
\text { yang sama dan } \\
\text { pada salah satunya } \\
\text { memiliki } \\
\text { perbedaan yang } \\
\text { diterapkan dengan } \\
\text { kurang baik }\end{array}$ \\
\hline - Berselang & $\begin{array}{l}\text { Terdapat susunan } \\
\text { bentuk, warna, } \\
\text { maupun ukuran } \\
\text { yang tidak sama } \\
\text { dan berselang } \\
\text { yang diterapkan } \\
\text { dengan sangat baik }\end{array}$ & $\begin{array}{l}\text { Terdapat susunan } \\
\text { bentuk, warna, } \\
\text { maupun ukuran } \\
\text { yang tidak sama } \\
\text { dan berselang } \\
\text { yang diterapkan } \\
\text { dengan baik }\end{array}$ & $\begin{array}{lr}\text { Terdapat } & \text { susunan } \\
\text { bentuk, warna, } & \text { waupun ukuran } \\
\text { maun } & \text { yang tidak sama } \\
\text { dan berselang } \\
\text { yang diterapkan } \\
\text { dengan cukup baik }\end{array}$ & $\begin{array}{lr}\text { Terdapat } & \text { susunan } \\
\text { bentuk, } & \text { warna, } \\
\text { maupun } & \text { ukuran } \\
\text { yang tidak } & \text { sama } \\
\text { dan } & \text { berselang } \\
\text { yang } & \text { diterapkan } \\
\text { dengan } & \text { kurang } \\
\text { baik } & \end{array}$ \\
\hline
\end{tabular}

Alat pengumpul data adalah tim penilai, dan instrumen penilaian dengan indikator penilaian. Teknik analisis data yaitu dengan observasi data, penggabungan (tabulasi) data, penyajian data, dan hasil akhir akandidapat melalui penghitungan sederhana dalam penjumlahan dan rata-rata pada nilai yang tertera dalam instrumen penilaian, kemudian di deskripsikan secara naratif.

\section{HASIL DAN PEMBAHASAN}

\section{SD. Negeri No. 058111 Kampung Satu}
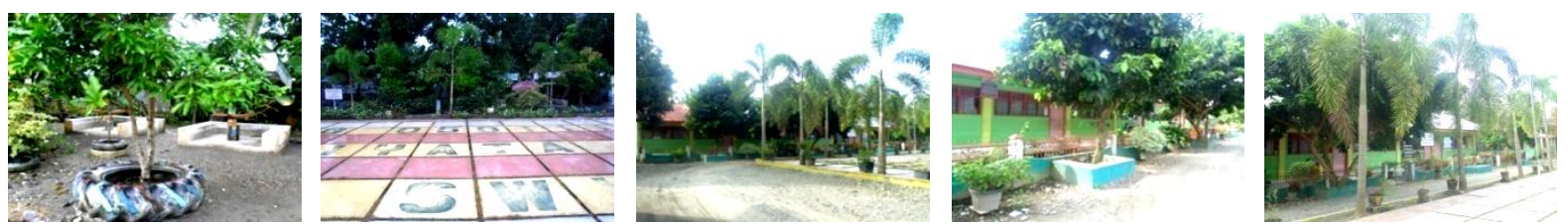
Tim penilai terdiri dari Penilai pertama (P-1) Bapak Zainul Fadli, S.E., Penilai kedua (P-2) Ibu Yosmalia Hasibuan, dan Penilai ketiga (P-3) Ibu Nurmawan Nadeak, S.Pd. Aspek material dengan rekayasa bentuk memiliki kesatuan pada keseimbangan dengan nilai rata-rata 4 (sangat baik), memiliki kesatuan pada pusat perhatian dengan nilai rata-rata 3.66 (baik), memiliki kesatuan pada irama dan pergerakan dengan nilai rata-rata 3.66 (baik), memiliki keseimbangan bersifat statis dengan nilai rata-rata 4 (sangat baik), memiliki pusat perhatian pada bentuk dengan nilai rata-rata 3.66 (baik), serta memiliki irama dan pergerakan bersifat progresif dengan nilai rata-rata 3.66 (baik). Aspek material dengan rekayasa tekstur memiliki kesatuan pada keseimbangan dengan nilai rata-rata 3.66 (baik), memiliki kesatuan pada irama dan pergerakan dengan nilai rata-rata 3 (baik), memiliki keseimbangan bersifat statis dengan nilai 3.66 (baik), serta memiliki irama dan pergerakan bersifat berselang dengan nilai 3 (baik).

Aspek material dengan rekayasa warna memiliki kesatuan pada keseimbangan dengan nilai rata-rata 3.33 (baik), memiliki kesatuan pada irama dan pergerakan dengan nilai rata-rata 4 (sangat baik), memiliki keseimbangan bersifat statisdengan nilai rata-rata 3.33 (baik), serta memiliki irama dan pergerakan bersifat berselang dengan nilai rata-rata 4 (sangat baik). Aspek material dengan rekayasa ukuran memiliki kesatuan pada keseimbangandengan nilai rata-rata 4 (sangat baik), memiliki kesatuan pada pusat perhatian dengan nilai rata-rata 3.66 (baik), memiliki kesatuan pada irama dan pergerakan dengan nilai rata-rata 3 (baik), memiliki keseimbangan bersifat statis dengan nilai rata-rata 4 (sangat baik), memiliki pusat perhatian pada ukuran dengan nilai rata-rata 3.66 (baik), serta memiliki irama dan pergerakan bersifat progresif dengan nilai rata-rata 3 (baik).

Aspek sirkulasi (jalanan) berdasarkan bentuk sirkulasi memiliki kesatuan pada keseimbangandengan nilai rata-rata 2.66 (cukup baik), serta memiliki keseimbangan bersifat statis dengan nilai rata-rata 2.66 (cukup baik). Aspek tata hijau berdasarkan peletakan tanaman memiliki kesatuan pada keseimbangan dengan nilai rata-rata 3 (baik), memiliki kesatuan pada irama dan dengan nilai ratarata 3 (baik), memiliki keseimbangan bersifat statis dengan nilai rata-rata 3 (baik), serta memiliki irama dan pergerakan bersifat berselang dengan nilai rata-rata 3 (baik). Aspek kenyamanan terhadap keindahan memiliki kesatuan 
pada keseimbangan dengan nilai rata-rata 3 (baik), memiliki kesatuan pada irama dan pergerkan dengan nilai rata-rata 3 (baik), memiliki keseimbangan bersifat statis dengan nilai rata-rata 3 (baik), serta memiliki irama dan pergerkan bersifat berselang dengan nilai rata-rata 3 (baik).
Rata-rata total penilaian dari penilai pertama adalah 3.17 (baik). Rata-rata total penilaian dari penilai kedua adalah 3.56 (baik). Rata-rata total penilaian dari penilai ketiga adalah 3.61 (baik). Rata-rata total penilaian dari tiga penilai adalah 3.44 (baik).

\section{SD. Negeri No. 050728 Pekan Tanjung Pura}
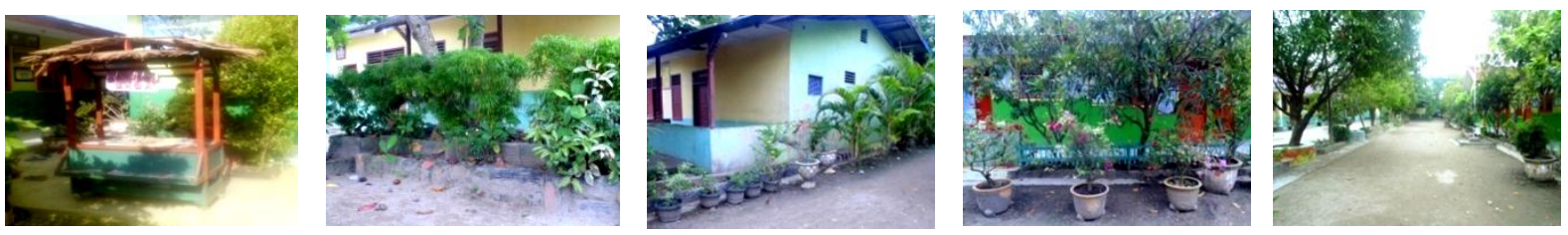

Tim penilai terdiri dari Penilai pertama (P-1) Bapak Zainul Fadli, S.E., Penilai kedua (P-2) Ibu Yosmalia Hasibuan, dan Penilai Ketiga (P-3) Ibu Sri Fadhillah, S.Pd. SD. Aspek material dengan rekayasa bentuk memiliki kesatuan pada keseimbangan dengan nilai rata-rata 3 (baik), memiliki kesatuan pada pusat perhatian dengan nilai rata-rata 2.66 (cukup baik), memiliki keseimbangan bersifat statis dengan nilai rata-rata 3 (baik), serta memiliki pusat perhatian pada bentuk dengan nilai rata-rata 2.66 (cukup baik). Aspek material dengan rekayasa tekstur memiliki kesatuan pada keseimbangan dengan nilai rata-rata 2.66 (cukup baik), serta memiliki keseimbangan bersifat statis dengan nilai rata-rata 2.66 (cukup baik). Aspek material dengan rekayasa warna memiliki kesatuan pada keseimbangan dengan nilai rata-rata 2.66 (cukup baik), serta memiliki keseimbangan bersifat statis dengan nilai rata-rata 2.66 (cukup baik).

Aspek material dengan rekayasa ukuran memiliki kesatuan pada keseimbangan dengan nilai rata-rata 3 (baik), memiliki kesatuan pada irama dan pergerakan dengan nilai rata-rata 3.33 (baik), memiliki keseimbangan bersifat statis dengan nilai rata-rata 3 (baik), serta memiliki irama dan pergerakan bersifat progresif dengan nilai rata-rata 3.33 (baik). Aspek sirkulasi (jalanan) berdasarkan bentuk sirkulasi memiliki kesatuan pada keseimbangan dengan nilai rata-rata 4 (sangat baik), serta memiliki keseimbangan bersifat statis dengan nilai rata-rata 4 (sangat baik). Aspek tata hijau berdasarkan peletakan tanaman memiliki 
kesatuan pada keseimbangan dengan nilai rata-rata 3 (baik), memiliki kesatuan pada irama dan pergerakan dengan nilai ratarata 3.66 (baik), memiliki keseimbangan bersifat statis dengan nilai rata-rata 3 (baik), serta memiliki irama dan pergerakan bersifat pengulangan dengan nilai rata-rata 3.66 (baik).

Aspek kenyamanan terhadap keindahan memiliki kesatuan pada keseimbangan dengan nilai rata-rata 4 (sangat baik), memiliki kesatuan pada irama dan pergerakan dengan nilai ratarata 4 (sangat baik), memiliki

\section{SMP. Negeri 1 Stabat}
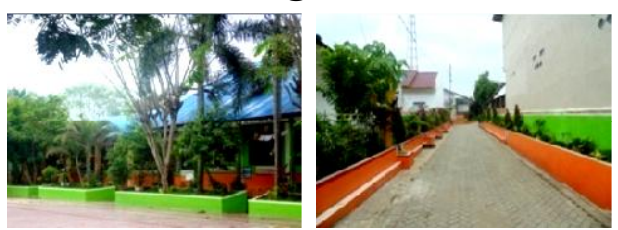

Tim penilai terdiri dari Penilai pertama (P-1) Bapak Zainul Fadli, S.E., Penilai kedua (P-2) Ibu Yosmalia Hasibuan, dan Penilai Ketiga (P-3) Ibu Hj. Marliah, S.Pd. Aspek material dengan rekayasa bentuk memiliki kesatuan pada keseimbangan dengan nilai rata-rata 2 (cukup baik), memiliki kesatuan pada irama dan pergerakan dengan nilai ratarata 2 (cukup baik), memiliki keseimbangan bersifat statis dengan nilai rata-rata 2 (cukup baik), serta memiliki irama dan pergerakan bersifat pengulangandengan nilai rata-rata 2 keseimbangan bersifat statis dengan nilai rata-rata 4 (sangat baik), memiliki irama dan pergerakan bersifat pengulangan dengan nilai rata-rata 4 (sangat baik), serta memiliki irama dan pergerkan bersifat pengulangan dengan nilai rata-rata 4 (sangat baik). Rata-rata total penilaian dari penilai pertama adalah 2.95 (cukup baik). Rata-rata total penilaian dari penilai kedua adalah 3.38 (baik). Rata-rata total penilaian dari penilai ketiga adalah 3.31 (baik). Rata-rata total penilaian dari tiga penilai adalah 3.21 (baik).
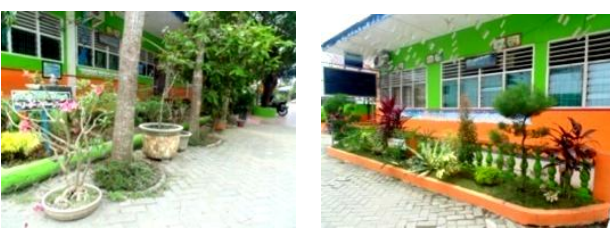

(cukup baik). Aspek material dengan rekayasa tekstur memiliki kesatuan pada keseimbangan dengan nilai rata-rata 2 (cukup baik), serta memiliki keseimbangan bersifat statis dengan nilai rata-rata 2 (cukup baik).

Aspek material dengan rekayasa warna memiliki kesatuan pada keseimbangan dengan nilai rata-rata 3.66 (baik), memiliki kesatuan pada irama dan pergerakan dengan nilai rata-rata 3.33 (baik), memiliki keseimbangan bersifat statis dengan nilai rata-rata 3.66 (baik), serta memiliki irama dan pergerakan 
bersifat berselang dengan nilai rata-rata 3.33 (baik). Aspek material dengan rekayasa ukuran memiliki kesatuan pada keseimbangan dengan nilai rata-rata 2 (cukup baik), memiliki kesatuan pada irama dan pergerakan dengan nilai ratarata 2 (cukup baik), memiliki keseimbangan bersifat statis dengan nilai rata-rata 2 (cukup baik), serta memiliki irama dan pergerakan bersifat berselangdengan nilai rata-rata 2 (cukup baik).

Aspek sirkulasi (jalanan) berdasarkan bentuk sirkulasi memiliki kesatuan pada keseimbangan dengan nilai rata-rata 3.66 (baik), serta memiliki keseimbangan bersifat statis dengan nilai rata-rata 3.66 (baik). Aspek tata hijau berdasarkan peletakan tanaman memiliki kesatuan pada keseimbangan dengan nilai rata-rata 2 (cukup baik), memiliki kesatuan pada irama dan pergerakan dengan nilai rata-rata 2.66 (cukup baik), memiliki

\section{SMA. Negeri 1 Padang Tualang}
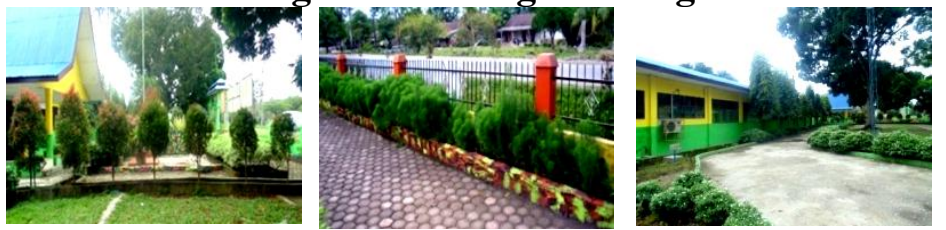

Tim penilai terdiri dari Penilai pertama (P-1) Bapak Zainul Fadli, S.E., Penilai kedua (P-2) Ibu Yosmalia Hasibuan, dan Penilai Ketiga (P-3) Bapak keseimbangan bersifat statis dengan nilai rata-rata 2 (cukup baik), serta memiliki irama dan pergerakan bersifat progresif dengan nilai rata-rata 2.66 (cukup baik).

Aspek kenyamanan terhadap keindahan memiliki kesatuan pada keseimbangan dengan nilai rata-rata 3.33 (baik), memiliki kesatuan pada irama dan pergerkan dengan nilai rata-rata 2.66 (cukup baik), memiliki keseimbangan bersifat statis dengan nilai rata-rata 3.33 (baik), memiliki irama dan pergerakan bersifat progresif dengan nilai rata-rata 2.66 (cukup baik), serta memiliki irama dan pergerakan bersifat berselang dengan nilai rata-rata 2.66 (cukup baik). Rata-rata total penilaian dari penilai pertama adalah 2.22 (cukup baik). Rata-rata total penilaian dari penilai kedua adalah 2.7 (cukup baik). Rata-rata total penilaian dari penilai ketiga adalah 2.66 (cukup baik). Rata-rata total penilaian dari tiga penilai adalah 2.52 (cukup baik). 
pada irama dan pergerakan dengan nilai rata-rata 2.66 (cukup baik), memiliki keseimbangan bersifat statis dengan nilai rata-rata 3 (baik), serta memiliki irama dan pergerakan bersifat progresif dengan nilai rata-rata 2.66 (cukup baik). Aspek material dengan rekayasa tekstur memiliki kesatuan pada keseimbangan dengan nilai ratarata 3.33 (baik), serta memiliki keseimbangan bersifat statis dengan nilai rata-rata 3.33 (baik).

Aspek material dengan rekayasa warna memiliki kesatuan pada irama dan pergerakan dengan nilai rata-rata 3 (baik), serta memiliki irama dan pergerakan bersifat progresif dengan nilai rata-rata 3 (baik).Aspek material dengan rekayasa ukuran memiliki kesatuan pada keseimbangan dengan nilai rata-rata 3 (baik), memiliki kesatuan pada irama dan pergerakan dengan nilai rata-rata 2.66 (cukup baik), memiliki keseimbangan bersifat statis dengan nilai rata-rata 3 (baik), serta memiliki irama dan pergerakan bersifat progresif dengan nilai ratarata 2.66 (cukup baik). Aspek sirkulasi (jalanan) berdasarkan bentuk sirkulasi memiliki kesatuan pada keseimbangan dengan nilai rata-rata 2.66 (cukup baik), serta memiliki keseimbangan bersifat statis dengan nilai rata-rata 2.66 (cukup baik). Aspek tata hijau berdasarkan peletakan tanaman memiliki kesatuan pada keseimbangan dengan nilai rata-rata 4 (sangat baik), memiliki kesatuan pada irama dan pergerakan dengan nilai rata-rata 3 (baik), memiliki keseimbangan bersifat statis dengan nilai rata-rata 4 (sangat baik), memiliki irama dan pergerakan bersifat pengulangan dengan nilai rata-rata 3 (baik), serta memiliki irama dan pergerakan bersifat progresif dengan nilai rata-rata 3 (baik).

2 Aspek kenyamanan terhadap кemuahan memiliki kesatuan pada keseimbangan dengan nilai rata-rata 3.33 (baik), memiliki kesatuan pada irama dan pergerkan dengan nilai rata-rata 4 (sangat baik), memiliki keseimbangan bersifat statis dengan nilai rata-rata 3.33 (baik), serta 
memiliki irama dan pergerakan bersifat progresif dengan nilai ratarata 4 (sangat baik). Rata-rata total penilaian dari penilai pertama adalah 2.98 (cukup baik). Rata-rata total penilaian dari penilai kedua adalah 3.14 (baik). Rata-rata total penilaian dari penilai ketiga adalah 3.21 (baik). Rata-rata total penilaian dari tiga penilai adalah 3.11 (baik).

Pada SD. Negeri No. 058111, prinsip desain kesatuan pada keseimbangan, pusat perhatian, serta pada irama dan pergerakan dinilai terpenuhi dengan keseimbangan yang cenderung bersifat statis atau formal, baik simetris maupun asimetris dilihat dari material ban, rumput dan lapangan olahraga, sirkulasi jalanan, serta susunan tanaman dan pepohonan. Pusat perhatian terpenuhi atas kesatuan pada bentuk dan ukuran material ban dengan pemberian warna terang yang dilihat menarik dari bentuk dan ukurannya mulai dari ban dengan ukuran kecil, hingga ban dengan ukuran besar sesuai sebagai pengganti pot, dan sebagai tempat duduk. Kesatuan irama dan pergerakan didapat dari bentuk dan ukuran progresif dari besar dan kecilnya material ban sebagai pengganti pot, pola potongan persegi pada lapangan olahraga berselang dengan rumput, pola warna pada lapangan olahraga, susunan berselang antara tanaman dan pepohonan dengan jarak yang sama, serta selang pada tanaman dan pepohonan pada pembatas jalanan atau sisi lapangan olahraga.

Pada SD. Negeri No. 050728, prinsip desain kesatuan yaitu pada keseimbangan, pusat perhatian, serta pada irama dan pergerakan dinilai terpenuhi dengan keseimbangan yang cenderung bersifat statis atau formal, baik simetris maupun asimetris dilihat dari bentuk gerobak baca, pembatas tanaman, susunan pepohonan dan tanaman, serta sirkulasi jalanan. Pusat perhatian terpenuhi atas kesatuan pada bentuk material gerobak baca dengan pemberian warna terang dan tambahan material atap rumbia. Material ini memberikan kesan baru, menarik, dan berbeda dari gerobak 3 la umumnya. Kesatuan irama ume rugerakan didapat dari susunan pengulangan pepohonan dengan 
ukuran tinggi, besar, jenis, dan jarak yang sama, serta pengulangan kelompok tanaman di bawahnya yang memiliki jenis, ukuran, dan jarak yang sama. Irama dan pergerakan progresif dilihat dari pembatas sirkulasi jalanan yaitu kelompok tanaman dengan ukuran kecil, sedang, dan besar, serta tanaman di bawah pepohonan yang memiliki ukuran, jenis, dan jarak yang sama.

Pada SMP. Negeri 1 Stabat, prinsip desain kesatuan yaitu pada keseimbangan, serta pada irama dan pergerakan dinilai terpenuhi dengan keseimbangan bersifat statis atau formal, baik simetris maupun asimetris dilihat dari bentuk dan warna pada pembatas tanaman, jarak yang sama pada susunan material keras maupun tanaman dan pepohonan, jenis dan ukuran tanaman maupun pepohonan, serta bentuk sirkulasi jalanan. Kesatuan irama dan pergerakan didapat dari susunan pengulangan pada pembatas kelompok tanaman, serta penerapan warnanya yang berselang, perbedaan dari pepohonan yang ditanam berselang atau di depan kelompok tanaman, dengan susunan progresif dari jenis, dan ukuran tanaman yang berbeda.

Pada SMA. Negeri 1 Padang Tualang, prinsip desain kesatuan yaitu pada keseimbangan serta pada irama dan pergerakan dinilai terpenuhi dengan keseimbangan bersifat statis atau formal, baik simetris maupun asimetris dilihat dari panjang dan lebar pembatas tanaman, serta susunan kelompok tanaman. Sedangkan keseimbangan yang bersifat statis terlihat dari rekayasa bentuk dan ukuran tanaman, tekstur perkerasan, bentuk sirkulasi jalanan yang berkelok, tata hijau, dan kenyamanan terhadap keindahan. Kesatuan irama dan pergerakan didapat dari susunan pengulangan jenis tanaman ataupun pepohonan dengan tinggi dan jarak yang sama. Irama dan pergerakan bersifat pengulangan dilihat dari jenis pohon yang sama namun berbeda tajuk, dan susunan kelompok tanaman berjenis sama, irama dan pergerakan progresif dari pola pengecatan warna pada pembatas tanaman, dan irama dan 
pergerakan progresif dari susunan tanaman berbeda jenis dan ukuran.

\section{SIMPULAN DAN SARAN}

Hasil penelitian dapat disimpulkan sebagai berikut:

1. Penataan Taman pada SD. Negeri No. 058111 Kampung Satu merupakan penataan taman formal yang memenuhi empat prinsip desain taman, yaitu kesatuan, keseimbangan, pusat perhatian, serta irama dan pergerakan dengan hasil baik.

2. Penataan Taman pada SD. Negeri No. 050728 Pekan Tanjung Puramerupakan penataan taman formal yang memenuhi empat prinsip desain taman, yaitu kesatuan, keseimbangan, pusat perhatian, serta irama dan pergerakan dengan hasil baik.

3. Penataan Taman pada SMP. Negeri 1 Stabatmerupakan penataan taman formal yang memenuhi tiga prinsip desain taman, yaitu kesatuan, keseimbangan, serta irama dan pergerakan dengan hasil cukup baik.

4. Penataan Taman pada SMA. Negeri 1 Padang Tualang merupakan penataan taman formal yang memenuhi tiga prinsip desain taman, yaitu kesatuan, keseimbangan, serta irama dan pergerakan dengan hasil baik.

Berdasarkan kesimpulan di atas, maka terdapat beberapa saran untuk melestarikan keindahan taman di sekolah penerima Adiwiyata di Kabupaten Langkat, di antaranya sebagai berikut:

1. Bagi pihak sekolah penerima Adiwiyata diharapkan selalu menanamkan pentingnya kepedulian terhadap lingkungan dalam hal ini taman sekolah kepada peserta didik, dengan tetap mengajarkan cara-cara yang baik dan sesuai dalam menata sebuah taman agar taman yang diciptakan mampu secara maksimal memberi keuntungan 

terhadap
kelestarian
lingkungan dan juga
menghadirkan keindahan.

2. Bagi Badan Lingkungan Hidup diharapkan melakukan pengawasan dan sosialisasi yang

berhubungan dengan

kelestarian lingkungan

hidup.

3. Bagi Dinas Pendidikan dan Pengajaran diharapkan selalu melakukan pendampingan, pengarahan, dan memenuhi kebutuhan akan penataan lingkungan dan kenyamanan sekolah yang lebih baik.

\section{DAFTAR RUJUKAN}

Ahmed, Zamiel. 2011. Aneka Jenis Kreasi dan Model Taman. Yogyakarta: Harmoni.

Budianto, Irmayanti M. 2007. Memahami Seni dan Estetika. Jurnal Wacana, vol. 9, no. 1, hal. 124-126. Depok: Universitas Indonesia.

Fontenot, Kathryn et al. 2010. Steps to Growing a Successful School Garden. Louisiana: LSU AgCenter (Research and Extension).
Hakim, Rustam. 2014. Komponen Perancangan Arsitektur Lansekap (Prinsip-Unsur dan Aplikasi Desain Edisi Kedua). Jakarta: PT. Bumi Aksara.

Herdiansyah, Haris. $2^{n 1 n}$ Metodologi Peneli 330 Kualitatif (Untuk IlmuSosial). Jakarta: Pen ..... Salemba Humanika.

Kartika, Dharsono Sony. 2007. Estetika. Bandung: Rekayasa Sains.

Patton, Michael Quinn. 1991. Metode Evaluasi Kualitatif. Terjemahan Budi Puspo Priyadi. 2009. Yogyakarta: Pustaka Pelajar.

Siskayati, Diana. 2009. Evaluasi Keberadaan dan Penggunaan Ruang Terbuka Hijau di Lingkungan Rumah Susun Provinsi DKI Jakarta. Ringkasan Skripsi. Bogor: Institut Pertanian Bogor.

Williams, Robin. 2007. The Garden Designer (Revised and Update Edition). London: Frances Lincoln Limited. 